Filozofska fakulteta, Univerza v Ljubljani

mojca.leskovec@ff.uni-lj.si

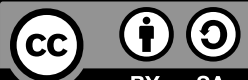

\title{
WEITBLICK: DAS GROßE PANORAMA: KURS- UND ÜBUNGSBUCH B2.1
}

Bajerski, Nadja/Böschel, Claudia/Meister, Hildegard/Würz, Ulrike/Herzberger, Julia/ Schäfer, Martina (2019). Weitblick: Das große Panorama: Deutsch als Fremdsprache: Kurs- und Übungsbuch B2.1. Berlin: Cornelsen Verlag. ISBN: 978-3-06-120889-9, mehka vezava, 208 strani, $19,99 €$.

UVOD

Učno gradivo za nemščino kot tuji jezik Weitblick B2.1 poleg pregledanega učbenika in delovnega zvezka obsega še aplikacije za učenje, avdioposnetke za prenos in kot zgoščenko ter digitalni in tiskani učiteljski priročnik. Dodatno gradivo ponujata tudi spletna stran http://www.cornelsen.de/codes in platforma Scook https://www.scook.de/, kjer je prav tako na voljo učbenik v e-obliki.

\section{2}

\section{ZASNOVA UČBENIKA}

Učbenik se prične $\mathrm{z}$ dvojno stranjo, namenjeno uvajanju $\mathrm{v}$ učno gradivo ter učenje $\mathrm{z}$ njim in s skupino. Sestavlja ga šest enot, vsakokrat z dvanajstimi stranmi, od tega šestimi stranmi vnosa besednih zvez in jezikovnih struktur prek besedil ter petimi stranmi modularnega dela, čemur sledi zaključna stran s povzetkom pomembnih besednih zvez enote. Medtem ko v rednem delu uporabniki in uporabnice uravnoteženo razvijajo vseh pet spretnosti, vključno s slušno-vidnim razumevanjem, pa tudi slovnico in besedišče ter učne strategije, je modularni del namenjen krepitvi spretnosti ter ponovitvi in poglobitvi besedišča in jezikovnih struktur, učitelju oz. učiteljici pa omogoča neposredno izvajanje notranje diferenciacije. Na zadnjih straneh učbenika najdemo obsežen pregled slovnice, sezname nepravilnih glagolov ter glagolov, samostalnikov in pridevnikov s predlogi, pa tudi stalnih zvez samostalnikov in glagolov. 
Učno gradivo z razvijanjem splošnih zmožnosti in specifičnih sporazumevalnih zmožnosti na višji ravni uresničuje temeljni cilj pouka nemščine kot tujega jezika, kot ga opredeljuje aktualni učni načrt za pouk nemščine v gimnaziji (UN 2008), tj. razvijanje medkulturne in medjezikovne zmožnosti. Dijaki in dijakinje ju razvijajo v okviru enot, naslovljenih Razširiti obzorje, Živeti z drugimi, Iskati in najti, Spoštljivo komunicirati, Nekoliko odklopiti in Predajati se spominom, ki se nanašajo na teme Medčloveški odnosi, Prosti čas in zabava, Kultura, umetnost, medkulturnost, Družina in stanovanje, Delo in poklic, storitvene dejavnosti, Znanost, tehnologija, množični mediji, Šola in izobraževanje, Narava in varstvo okolja, Telo in zdravje ter Politika in družba, priporočene v UN-ju (2008). Pri tem je vsaka tema predstavljena z različnih vidikov; tema Živeti z drugimi na primer vključuje podteme Kako bi želeli živeti?, Odnosi v digitalni dobi, Premagovati predsodke, Ženske so nečimrne. Moški? Nikoli!, Ko se srečajo kulture in Iti do svojih meja. Nabor tem, obravnavanih na predhodnih ravneh učenja, učno gradivo tako nadgrajuje, hkrati pa upošteva individualnost posameznega uporabnika/uporabnice.

Poleg zmožnosti sporazumevanja v tujem jeziku z gradivom Weitblick B2.1 dijaki in dijakinje razvijajo tudi preostale ključne kompetence za vseživljenjsko učenje, še posebej digitalno pismenost in učenje učenja. Gradivo jim poleg že običajnega e-učbenika in spletnih interaktivnih vaj namreč ponuja široko digitalno podporo prek brezplačno dostopnih aplikacij $\mathrm{z}$ avdio- in videoposnetki k enotam ter dodatnimi nalogami različnih ravni zahtevnosti in navedbami spletnih povezav za nadaljnje raziskovanje - vse to po motu prinesi svojo napravo (BYOD) preprosto dostopno s pametnim telefonom ali tablico. Sposobnost učinkovitega obvladovanja lastnega učenja krepijo jasna zgradba gradiva, sprotna navedba učnih ciljev v učbeniških enotah, preglednica najpomembnejših besednih zvez enote na njeni vsakokratni zadnji strani in predvsem eksplicitno urjenje učnih strategij. Dijaki in dijakinje z učbeniškim gradivom prav tako razvijajo literarne zmožnosti ter tako krepijo kulturno zavest in izražanje.

Z gradivom Weitblick B2.1 dijaki in dijakinje v nemščini kot ciljnem jeziku uravnoteženo dalje razvijajo ne le receptivne in produktivne zmožnosti, temveč skladno z novimi dopolnitvami dokumenta SEJO (2018) poudarjeno tudi interakcijo in mediacijo ter medkulturno in raznojezično zmožnost. Slovnično zmožnost kot ključni sestavni del sporazumevalne zmožnosti razvijajo s samostojnim odkrivanjem jezikovnih zakonitosti, kar dopolnjujejo nazorni prikazi v enotah in napotitve $\mathrm{v}$ slovnične preglednice na koncu učbenika. Ponavljanje besedišča ciljnega jezika in usvajanje novih besednih zvez poteka v okviru besedil, $\mathrm{z}$ raznoliko vizualno podporo. $\mathrm{Z}$ nalogami iz uveljavljenih izpitnih formatov na zadnjih straneh enot $v$ delovnem zvezku in posredovanimi učnimi strategijami, naborom vaj za slušno in bralno razumevanje ter rabo jezika (vstavljanje slovničnih in pomenskih besed, besedotvorje, pretvorbe), pa tudi pisno sporočanje in ustno izražanje je gradivo hkrati ustrezen pripomoček za pripravo na splošni maturitetni izpit iz nemščine na višji ravni. 


\section{$4 \quad$ METODIČNO-DIDAKTIČNI PRISTOP}

Pristop učnega gradiva Weitblick B2.1 povzemajo naslednja didaktično-metodična načela: medkulturnost in raznojezičnost ter usmerjenost $\mathrm{k}$ opravilom in uporabniku/uporabnici. Učno gradivo spodbuja pluralne pristope in vključevanje drugih jezikov v proces učenja tako ne ostaja več le v domeni učitelja oz. učiteljice. S simulacijami raznolikih situacij Weitblick B2.1 uporabnike in uporabnice nadalje pripravlja na avtentično rabo jezika. Pri tem nagovarja različne učne tipe in upošteva raznolikost učnih slogov, tako v rednem kot v modularnem delu enot pa omogoča notranjo diferenciacijo pri vsebini in nalogah ter $\mathrm{s}$ tem upoštevanje različnega predznanja in siceršnjih individualnih posebnosti. Z izborom aktualnih tem, kot so blogi, digitalizacija delovnega procesa, ekstremni šport, študij v tujini, gradivo pritegne zanimanje mlajših odraslih in ohranja njihovo motivacijo za učenje.

\section{5} ZAKLJUČEK

Ocenjujem, da gradivo Weitblick B2.1 uporabnike in uporabnice uspešno pripelje prek ravni sporazumevalnega praga na višjo raven samostojne uporabe nemščine kot ciljnega jezika. Navaja jih na sprejemanje kompleksnih besedil o konkretnih in abstraktnih temah, učinkovito argumentiranje in tvorjenje poglobljenih besedil širokega nabora tem ter krepi njihovo jezikovno zavedanje in sposobnost uveljavljanja $\mathrm{v}$ družabnem diskurzu. Učno gradivo je pri tem usklajeno tako z veljavnim področnim učnim načrtom (2008) kot z najnovejšimi spoznanji o učenju in poučevanju tujega jezika ter že upošteva tudi dopolnitve k dokumentu SEJO (2018). 